\title{
Histological Study of the Prostate and Vesicular Glands in Eastern European hedgehog (Erinaceous concolor)
}

\author{
Banan Khojasteh $\mathbf{S M}^{1 *}$, Rodbari. $\mathbf{F}^{1}$, Halimi Tabrizi. $\mathbf{F}^{1}$ and Delashoub. $\mathbf{M}^{2}$
}

${ }^{1}$ Department of Animal Biology, Faculty of Natural Sciences, University of Tabriz, Tabriz, Iran

2Department of Basic Sciences, Faculty of Veterinary Medicine, Tabriz Branch, Islamic Azad University, Tabriz, Iran

"Corresponding author: Banan Khojasteh SM, Associate Professor of Animal Biology, Department of Animal Biology, Faculty of Natural Sciences, University of Tabriz, Tabriz, Iran, Tel: +984113392728; Fax: +984113356027; E-mail: smbanan@tabrizu.ac.ir

Received date: April 9, 2014, Accepted date: June 28, 2014, Published date: July 5, 2014

Copyright: ( 2014 Khojasteh, et al. This is an open-access article distributed under the terms of the Creative Commons Attribution License, which permits unrestricted use, distribution, and reproduction in any medium, provided the original author and source are credited

\begin{abstract}
In present study, Prostate and seminal vesicle gland are investigated to determine their histological structure five prostates and seminal vesicles from adult hedgehogs that had no clinical evidences were evaluated. The description of the histological characteristics of glands was determined by light microscopy after removed and fixation of tissue samples, providing of $6-7 \mu$ sections and staining with hematoxylin/eosin. Results showed that the prostate is surrounded by connective tissue capsule and trabeculae from the capsule divide the gland into many compartments. Each compartment was lined with simple columnar epithelium. The seminal vesicle gland was observed to be divided by the connective tissue trabeculae. Epithelium of this gland was simple columnar with apical blebs.
\end{abstract}

Keywords: Histology; Prostate; Vesicular gland; Eastern European hedgehog

\section{Introduction}

The male accessory sex glands of mammals include the prostate gland, the vesicular glands, the glands of the ampulla and the bulbourethral glands. These glands depend on androgen and play an important role in the reproductive function [1,2]. Macroscopic and microscopic anatomy of these glands varies widely among different species of mammalian vertebrates [3]. Histology of Prostate and vesicular glands have studied in some mammals with almost different findings [1]. Hedgehogs are minute mammals of Erinaceidae family. These exotic pets are nocturnal and their body is coated with spiny like needles. Recently they are receiving a great attention among pet owners. These animals have become increasingly popular as an exotic household pet due to being unique, cute, and low and ways maintenance pets [4]. The aim of the present study was to histological evaluate the prostate and vesicular gland in Eastern European hedgehog (Erinaceous concolor).

\section{Materials and Methods}

This investigation was performed on 5 healthy and adult male hedgehogs. Animals were captured from suburbs of Tabriz city of East Azerbaijan, Iran and euthanized by intra-peritoneal injection of sodium pentobarbital $(250 \mathrm{mg} / \mathrm{kg})$. The research protocol was approved by the ethical committee of the University of Tabriz. The prostate and vesicular glands were dissected out and tissue samples fixed by immersion in \%10 formalin. Then samples dehydrated in graded ethanol, cleared in xylen, impregnated and embedded in paraffin wax. Sections of $6-7 \mu$ thick were obtained with Leitz microtome model 1512 and stained with hematoxylin/eosin (H \& E) [5]. All the slides were examined and photographed with an Olympus $\mathrm{BH}-2$ light microscope to evaluate the histological features.

\section{Results}

The findings showed that the wall of prostate gland was consisted of a connective tissue capsule. From the capsule, many trabeculae divided the gland into fluid filled lobes (Figure 1). The mucosa (epithelium and lamina propria) was thrown into branching folds. The epithelium of the prostate was simple columnar supported by basement membrane (Figures 2 and 3). Almost round nuclei and prominent central nucleolus were observed in epithelium. The vesicular gland was observed to be surrounded by connective tissue capsule with trabeculae originating from it (Figure 4). The gland was lined with simple columnar cells of varying heights with oval Nuclei (Figure 5). These secretory epithelium had surface blebs (large flaccid vesicles) giving a ragged appearance to the cells (Figure 6).

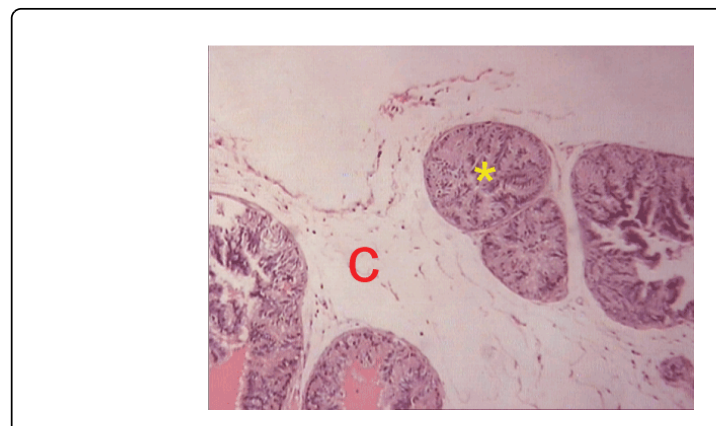

Figure 1: Section of the prostate gland. Note the compartment (star) and connective tissue trabecule $(\mathrm{C}) .(\times 40, \mathrm{H} \& \mathrm{E})$. 
Citation: Banan Khojasteh SM, Rodbari F, Halimi Tabrizi F, Delashoub M (2014) Histological Study of the Prostate and Vesicular Glands in Eastern European hedgehog (Erinaceous concolor). Biol Med 6: 205. doi:10.4172/0974-8369.1000205

Page 2 of 3

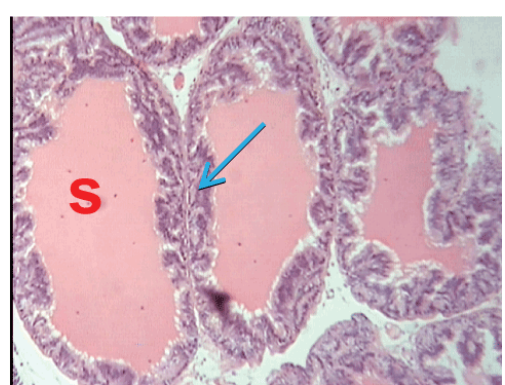

Figure 2: Fluid Filled compartment (S) and epithelium (arrow) of the prostate gland. $(\times 40, \mathrm{H} \& \mathrm{E})$.

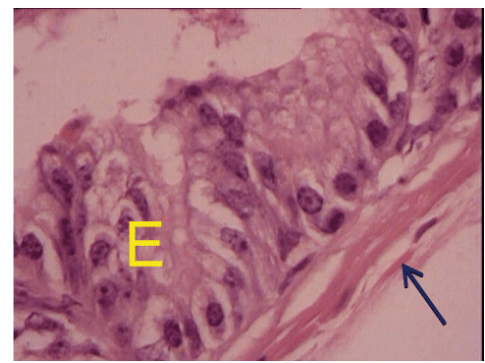

Figure 3: Simple columnar epithelium (E) and connective tissue between compartments (arrow) of the prostate gland. $(\times 400, \mathrm{H} \&$ E).

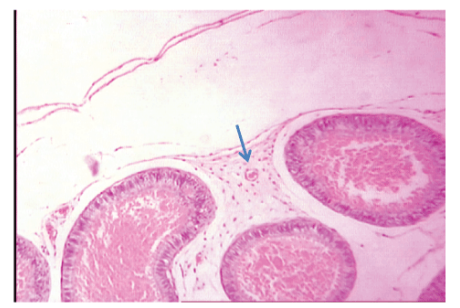

Figure 4: The vesicular gland. Secretory compartment (star) and connective tissue (arrow), ( $\times 40, \mathrm{H} \& \mathrm{E})$.

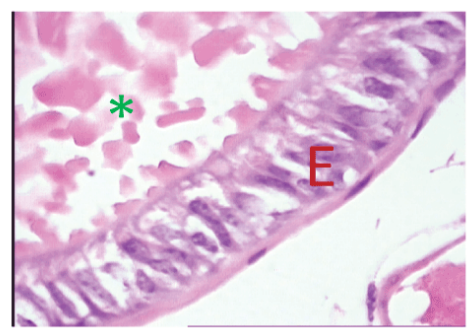

Figure 5: Epithelium of the vesicular gland (E) and accumulated fluid in compartment (Star). ( $\times 400, \mathrm{H} \& \mathrm{E})$.

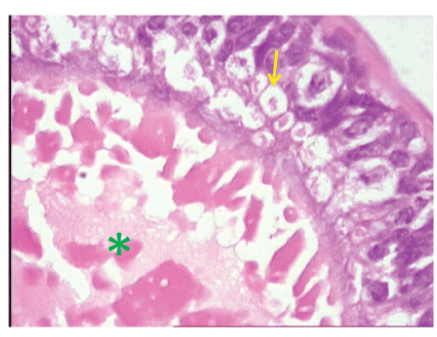

Figure 6: Simple columnar epithelium of the vesicular gland with surface blebs (arrow) and fluid in compartment (star). $(\times 400$, $\mathrm{H} \& \mathrm{E})$.

\section{Discussion}

Accessory sex glands are important in reproductive functions of mammals. Some researchers have showed that secretions of accessory sex glands influence sperm physiology and fertilization. From another prospective, secretions of the accessory sex glands are able to enhance the fertilizing capacity of some domestic animals sperm [6,7]. So, the histological and physiological study of these glands can help in understanding of reproductive biology of mammals. It has been revealed that in the stallion and dog, the epithelium of the prostate gland is consisted of tall columnar secretory cells that are similar to findings of the present study.

Adebayo et al. [1] have reported that in greater cane rat (Thryonomys swinderianus, Temminck) the prostate is surrounded by connective tissue capsule and compartments are lined with simple columnar cells containing nuclei with eccentrically located nucleoluses. In Caspian miniature horse, the secretory epithelium of prostate is cuboidal to columnar and/or pseudostratified [8].

Vesicular glands of Eastern European hedgehog is almost similar to other mammals is having simple columnar epithelium [1]. In carnivores these glands are absent but are true vesicles in the stallion. In bull the secretory epithelium of vesicular glands is tall columnar with apical blebs that is similar with the results of present study [2].

\section{References}

1. Adebayo AO, Oke BO, Akinloye AK (2009) The gross morphometry and histology of the male accessory glands in the Greater Cane rat (Thryonomys swinderianus, Temminck). Journal of Veterinary Anatomy 2: 41-51.

2. Aughey E, Frye FL (2001) Comparative Veterinary Histology. Manson Publishing 174-175.

3. Thomson AA1, Marker PC (2006) Branching morphogenesis in the prostate gland and seminal vesicles. Differentiation 74: 382-392.

4. Youssefi MR, Rahimi MT, Halajan A, Moosapour AA, Nikzad R, et al. (2013) Helminth parasites of Eastern European hedgehog (Erinaceous concolor) in Northern. Iran. Iranian Journal of Parasitology 8: 645- 650.

5. Bancroft JD, Stevens A(1977) Theory and Practice of Histological Techniques. Churchill Livingstone, 10-45.

6. Henault MA1, Killian GJ, Kavanaugh JF, Griel LC Jr (1995) Effect of accessory sex gland fluid from bulls of differing fertilities on the ability of cauda epididymal sperm to penetrate zona-free bovine oocytes. Biol Reprod 52: 390-397. 
Citation: Banan Khojasteh SM, Rodbari F, Halimi Tabrizi F, Delashoub M (2014) Histological Study of the Prostate and Vesicular Glands in Eastern European hedgehog (Erinaceous concolor). Biol Med 6: 205. doi:10.4172/0974-8369.1000205

Page 3 of 3

7. Moura AA1, Chapman DA, Koc H, Killian GJ (2007) A comprehensive proteomic analysis of the accessory sex gland fluid from mature Holstein bulls. Anim Reprod Sci 98: 169-188.

8. Sodagar Amiri A, Rezaian M, Gilanpour H, Adib Moradi M, Rostami M, et al. (2010) Anatomical and histological study of accessory sex glands in
Caspian miniature horse. Veterinary Journal of Islamic Azad University 7: $11-16$ 